\title{
HEALTH SELF-EVALUATION IN REGIONS OF LATVIA: THE DEVELOPMENT OF THE SITUATION AND CHALLENGES
}

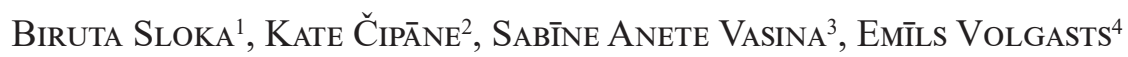 \\ University of Latvia (Latvia)
}

\begin{abstract}
The self-evaluation of health in Latvia has recently gained a special awareness, due to the financing for health being among the lowest in the European Union. Latvia has recently faced various difficulties, such as problems paying the salaries of medical personnel, and medical personnel emigrating to work in other countries.

The aim of the study is to analyse the self-evaluation of health by inhabitants in the regions of Latvia.

Research methods used in the preparation of this paper: the analysis of scientific publications and results of previously conducted research; the analysis of the results of a survey on household income and expenses conducted by the EU-SILC and the European Central Bank, compared with the results from other EU countries. The results of the survey are analysed using descriptive statistics indicators and cross-tabulations for the regions of Latvia. For areas, urban-rural living and ANOVA analysis of variance are used. To analyse self-evaluations by regions, the correlation of the relationship between health self-evaluation and educational level is used. The results of the analysis indicate that the situation of the regions of Latvia in the context of health self-evaluation is very different, and that there are very big demands on decision makers to find the best possible solution.
\end{abstract}

KEY WORDS: self-evaluation of health, self-perceived health, population health, regional development, EU-SILC, Latvia.

JEL CODES: K2; K11

DOI:

\section{Introduction}

The analysis of the self-evaluation of health is essential for a country, and it is also important to ascertain whether the numbers of households which cannot afford basic items for a normal standard of living are growing or decreasing. According to the statistics, more than 600,000 people have left Latvia since 1991 (CSB of Republic of Latvia, 2019B). There is an especially dramatic situation in the regions, where the standard of living is lower than in the towns, and the number of problems related to health care is increasing.

Taking into account all these factors, the purpose of this study is to analyse the self-evaluation of health in the regions of Latvia, to analyse the self-evaluation of the health of inhabitants according to urban and rural areas, and to investigate the significance of differences in self-evaluations of health.

In order to achieve these aims, the tasks were formulated as follows:

1) to review the theoretical background of health self-evaluation in the context of regional development;

2) to review existing research on health self-evaluation in the regions of the EU;

3) to analyse the level of health self-evaluation in the regions of Latvia.

1 Biruta Sloka, University of Latvia, Department of Management Sciences. Scientific field: management and economics. E-mail: Biruta.Sloka@lu.lv. Tel.:+37129244966.

2 Kate Cipane, University of Latvia, Department of Management Sciences. Scientific field: management and economics. E-mail: katecipane@gmail.com. Tel.: + 37120220183.

3 Sabine Anete Vasina, University of Latvia, Department of Management Sciences. Scientific field: management and economics. E-mail: sabine_anete.vasina@lu.lv. Tel.: + 37126095294.

4 Emils Volgasts, University of Latvia, Department of Management Sciences. Scientific field: management and economics. E-mail: e.volgasts@gmail.com. Tel.: + 37129727027. 
The research methods used were: the analysis of the results of research publications and previously conducted research, the analysis of the results of 'The European Union Statistics on Income and Living Conditions' (EU-SILC) (in 2014-2017), and the results of the survey of household income and expenses (HFCS) conducted by the European Central Bank. The results are compared with results from other European countries. For the analysis of statistical data, the main indicators of descriptive statistics (arithmetical means, mode, median, range, standard deviations and standard error of means) are used; $\mathrm{t}$ - test for testing differences of means by two independent characteristics, areas (cities and rural areas). For testing differences of arithmetical means by six independent characteristics, the regions of Latvia, one of the most often used multivariate analysis methods was used: the analysis of variance ANOVA and correlation analysis to analyse the relationship between self-evaluation of health and educational level.

1. Theoretical findings on self-evaluation of health in the regions: the theoretical framework

The life of neighbourhood communities is considered to be an important determinant of the overall health and well-being of the population, and it is believed that investment in public health policies improves the health of the population. It is believed that results in the health of the population are acquired through physical resources and the social environment (Perez, Braen, Boyer et al., 2019). Over recent years, the fact that neighbourhood characteristics also have a big impact on the health and well-being of children, as well as the fact that the interest of many researchers has focused on neighbourhoods and development, especially on neighbourhood disorganisation and related characteristics, such as instability (Liu, Kia-Keating, Santacrose, Modir 2018: 204), has been discussed. According to Zhang et al. (Zhang, Zhou, Kwan 2019), most of the studies on neighbourhood health have been conducted based on two health dimensions (e.g., body mass index, diseases, mental health) or general health (self-rated health) and other factors (Simanskiene, Kutkaitis, Buciene 2013: 156; Kuhlmann 2003:92).

According to Eurostat (Eurostat, 2017) self-perceived health statistics, $67.5 \%$ of the EU-28 population aged 16 or over reported their health was good or very good in 2016 . The highest health ratings perceived were in Ireland (82.4\%), Cyprus (78.7\%), Switzerland (77.7\%) and Norway (77.1\%). Self-perceived health in Latvia was 47.2\%, the second-lowest rating among the EU-28 after Lithuania (43.4\%).

Academic research in many countries indicates that the results of the self-evaluation of health are an important indicator for evaluating the situation in the respective country, for the needs of employment, health management, and other aspects (Vîrga, Rusu, 2018: 270). Food quality and consumption preferences influence the situation of health and the self-evaluation of health (Lin, Shih, Lin 2017: 249). It has been stated that self-rated health (SRH) is the most widely used assessment tool, and the interpretation of it varies by age and socio-economic position. Chaparro et al. (2019) analysed UK Household Longitudinal Study nurse visits, to understand whether the different reporting of self-rated health exists, and concluded that different social groups rate their health considering different health dimensions.

According to Woolf (2019:196), the health of the population is shaped by five domains: health care, health behaviour, the physical and social environment, socio-economic status, and social policy. One of the most important factors influencing the health of the population is socio-economic status, e.g., in developed countries, people can afford medical care and to live in healthy neighbourhoods. Social policy is thought to influence all the domains, but it also has the negative impact of shaping social divisions and creating neglected neighbourhoods.

The importance of the neighbourhood on individual health has been on the research agenda before, and it has been established that a person's health is affected by the neighbourhood they live in. It is accepted that effects such as median income, the unemployment rate, indices of multiple deprivation, and other factors that are subjective, such as perceived neighbourhood quality, perceived cohesion and safety, have a big impact on health outcomes. It is believed that more deprived neighbourhoods are more likely to report worse health, in comparison with less deprived neighbourhoods, especially among households of older adults (Godhwani, Jivraj, Marshall, Becares 2019: 53), and depending on other aspects (Šimanskienė, Burbulytė-Tsiskarishvili 2013: 631; Smyth, Lindsay, Brennan, Lindsay 2017: 421; Gustainienè, Endriulaitienè 2009: 53). 
A study of elderly Taiwanese (Wang, Wu, Zhang, Tsay 2019: 84) revealed that emotional support for adult children and leisure care for grandchildren were significantly associated with better self-rated health, but financial and instrumental support do not influence self-rated health. Also, participation in religious groups and community clubs are significantly associated with self-rated health, and older Taiwanese who believed in their ability to adapt to change and who control their own lives, who are able to make new friends, and who maintained a self-reliant and regular weekly schedule, are healthier, which shows the importance of social participation among the elderly. Factors which are associated with a poor and fair self-perception of health for women in Columbia (Mendoza-Romero, Urbina, Cristancho-Montenegro, Rombaldi 2019: 6) are cigarette smoking and a lack of physical activity. Other factors associated with low self-rated health are age, poor schooling, low to medium socio-economic status, and no affiliation with the health system.

Self-rated health has also been researched in China among older people using a national survey of elderly people in the context of social exclusion (Feng, Jones, Phillips 2019: 239). It has been established that over recent years, the world has been facing various difficulties, one of which is social exclusion among older people, because of global demographic ageing patterns, ongoing economic instability, and the ageing cohorts that increase inequality. Self-rated health in association with household wealth and income has been researched in Finland among middle-aged men and women in 2010 (Aittomaki, Martikainen et al., 2010: 1018). It was concluded that low household wealth is strongly associated with poor self-related health, therefore stressing the importance of income levels on the self-assessment of health, as well as the importance to well-being of being able to access care on health issues (Simola 2019: 312: Ronda, Van Assema, Ruland, Steenbakkers, Brug 2003: 358).

\section{Empirical research results}

The EU-SILC survey is the most complete harmonised survey on household income in Europe. It is conducted annually in line with Eurostat methodology in all European Union countries. In order to collect information, three questionnaires were developed: Household Register, Household Questionnaire Form, and Individual Questionnaire Form.

One of the main study objects of the EU-SILC survey is the health self-evaluation of a household, its composition and level. In 2017, the sample size of EU-SILC in the Republic of Latvia was 8,087 randomly selected respondents. Completed sets of questionnaires were received from 6,014 households. Individual interviews (persons) numbered 11,304. The non-response rate was 25.6\% (CSB of Republic of Latvia, 2019).

It is important that anonymised data sets are available in SPSS files for more detailed statistical data analysis, by statistical regions, by areas (cities or rural areas), by household size, and by other indicators which are available to researchers for deeper analysis.

\subsection{Health financing in the EU}

Health care in the European Union is financed in different ways across all member states; however, access to quality health care at an affordable cost is widely regarded as a basic need in all EU member states. Health care expenditure in the EU relative to GDP is given in Figure 1.

The statistics show that the health-care expenditure was highest in Switzerland, which spends more than $12 \%$ of GDP on health care, followed by Germany, France and Sweden. Romania, Luxembourg, Liechtenstein and Latvia spent the least. Of the Baltic States, Latvia has the lowest health-care expenditure; however, Estonia and Lithuania have very similar spending.

The statistics show that Latvia has the lowest number of people aged 16 to 29 years who rate their health as good or very good among EU member states. Of the Baltic States, Lithuania and Estonia are in a slightly better position, but still far below the EU average. Greece, Romania and Cyprus have the highest number of people aged 16 to 29 who rate their health as good or very good; while Portugal, Italy and Latvia have the lowest. 


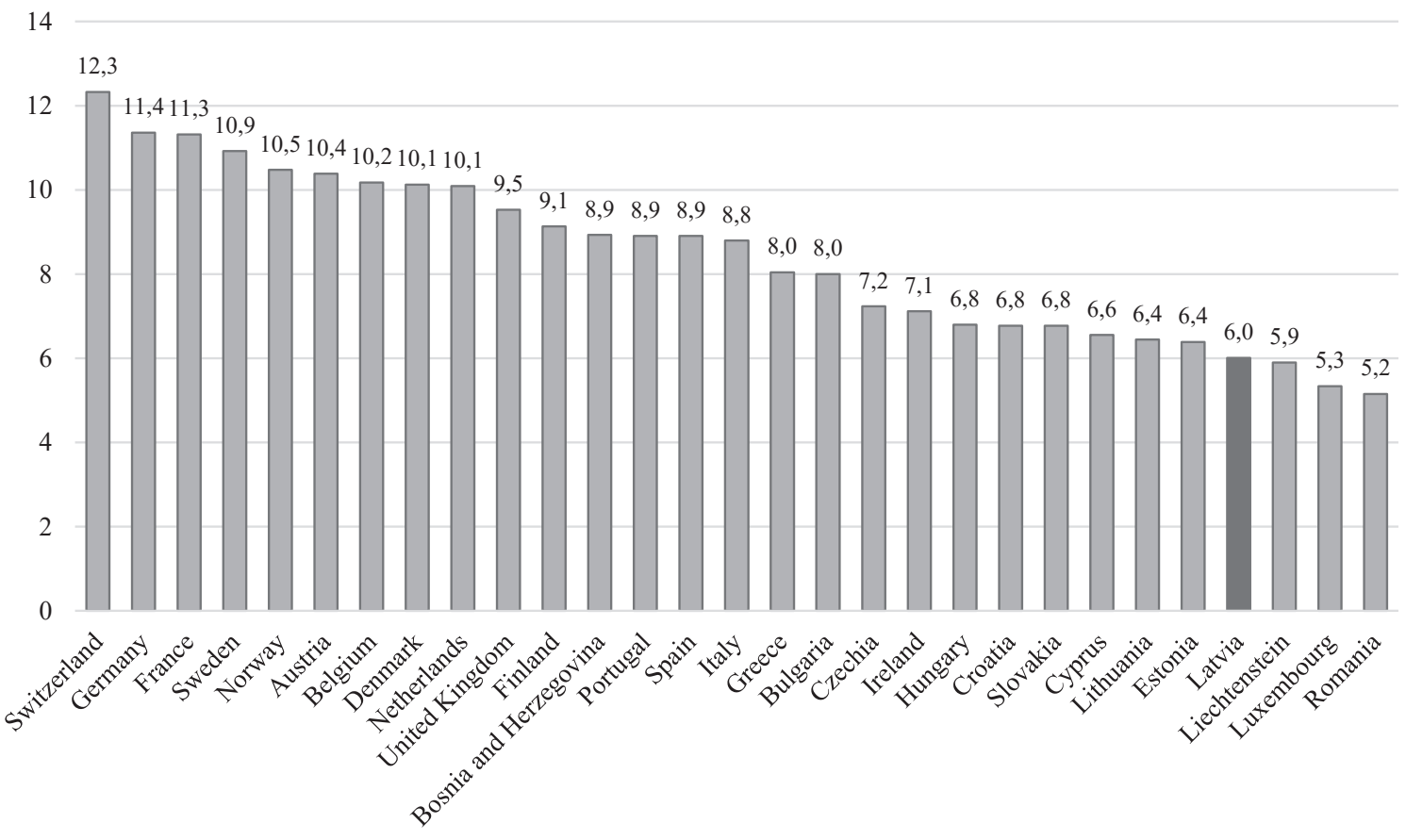

Figure 1. Health care expenditure in Europe in 2017 (\% of GDP) (except Poland, Malta and Slovenia, as data is not available).

Source: Authors' calculations on Eurostat data.

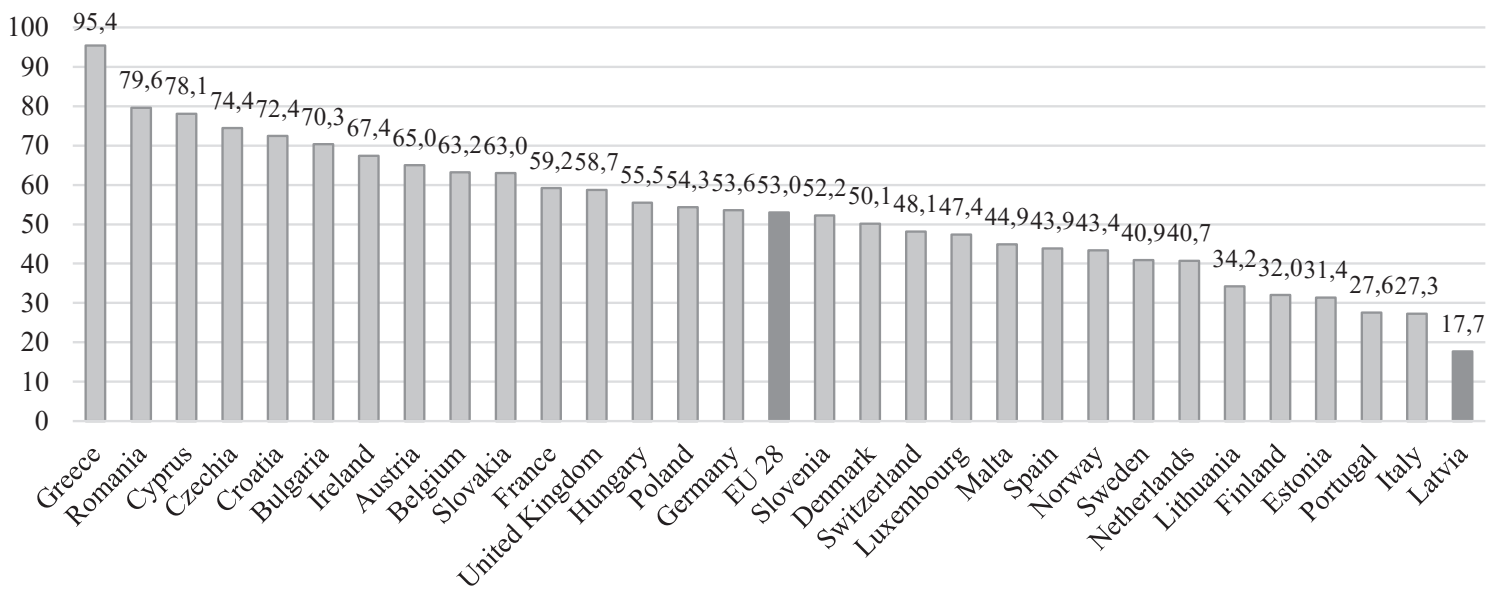

Figure 2. Share of persons aged 16 to 29 with good and very good self-perceived health in 2016.

Source: Authors' calculations on Eurostat data. 
Another obstacle that reflects on citizens of Latvia is the value added tax (VAT) rate on prescription-only drugs. While Latvia has one of the lowest expenditures on health care in the EU, it also has one of the highest VAT rates on prescription-only drugs. The VAT rate information on prescription-only drugs is given in Figure 2.

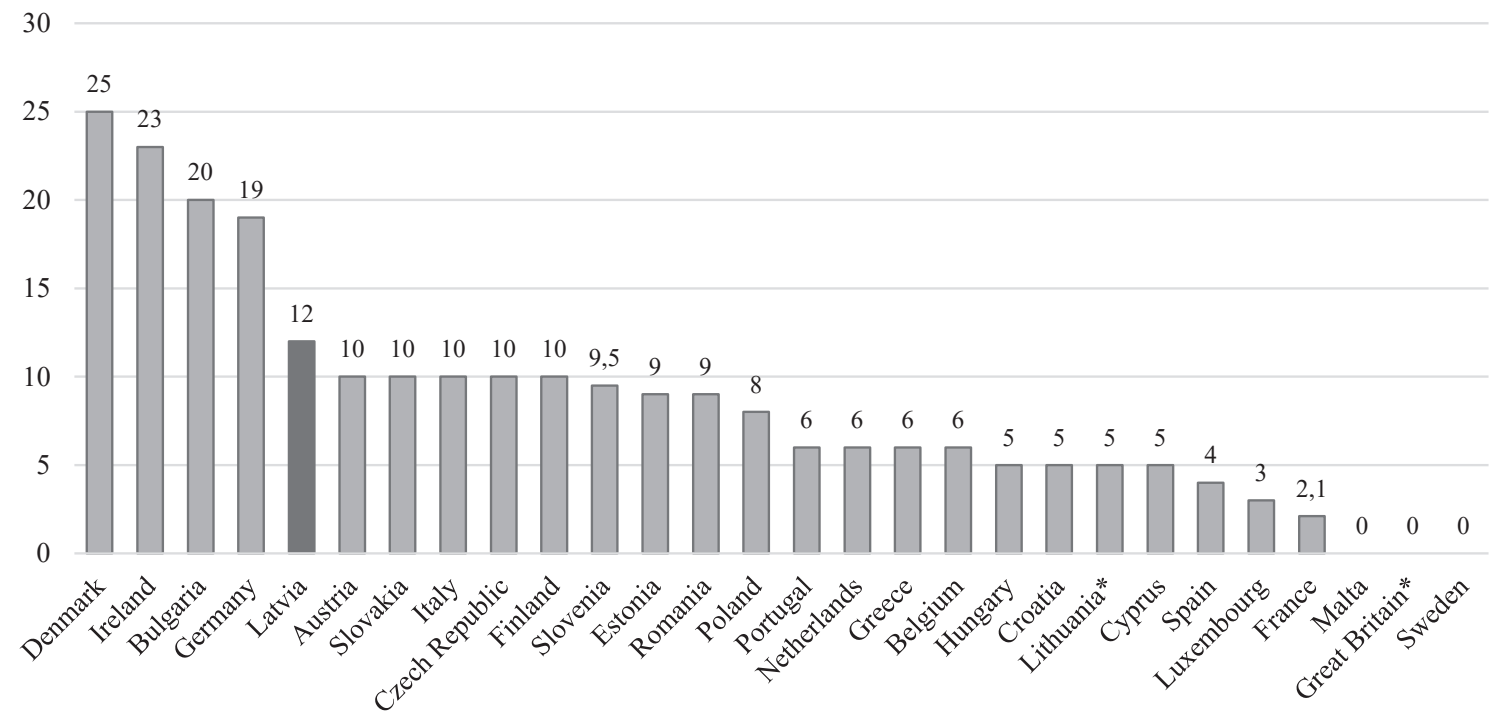

Figure 3. The Value Added Tax (VAT) rate on prescription-only drugs in Europe in 2018, by country (*Great Britain: non-prescription drugs $20 \%$, pharmaceutical drugs prescribed by the NHS $0 \%$. Lithuania: pharmaceuticals $21 \%$, starting 31 December 2013).

Source: Authors' chart on Statista data.

The statistics show that in 2018, the highest VAT rate on prescription-only drugs in Europe was in Denmark; and the lowest was in Malta, Great Britain and Sweden. Like other significant information, the authors have found and want to highlight the fact that Latvia has the fifth-highest VAT rate on prescription-only drugs in Europe, and the highest VAT rate on prescription-only drugs in the Baltic States.

\subsection{Health self-evaluation: the case of Latvia}

The situation in the health-care sector is very tense at the moment; however, in recent years, the issue of health care has been of concern to both inhabitants and health-care workers, and politicians and several nongovernmental institutions have raised the question of the low salaries and the huge emigration of medical workers, creating a very problematic situation in Latvia. The main statistical indicators of health self-evaluation by inhabitants of Latvia are included in Table 1.

The statistics show that the evaluation for self-evaluated health is around the average level, and half of respondents evaluated their health as good or very good, but the other half as bad or very bad (indicated by the median). Usually the evaluation is also the average (characterised by mode with a value of 3). Although the whole evaluation scale was used, and indicators of variability are high for self-evaluations of health, the distribution of the responses varies: the distribution of responses on respondents' self-evaluated health in Latvia in 2017 are given in Table 2. 
Table 1. The main statistical indicators of health self-evaluation by inhabitants of Latvia in 2017 .

\begin{tabular}{|l|l|l|}
\hline $\mathrm{N}$ & Valid & 10933 \\
\cline { 2 - 3 } & Missing & 0 \\
\hline Mean & 2,81 \\
\hline Standard error of mean & 0,008 \\
\hline Median & 3 \\
\hline Mode & 3 \\
\hline Standard deviation & 0,858 \\
\hline Range & 4 \\
\hline Minimum & 1 \\
\hline Maximum & 5 \\
\hline
\end{tabular}

Source: Authors' calculations on EU-SILC data, $\mathrm{n}=10933$.

Evaluation scale 1-5: where 1= very good, 5 = very bad.

Table 2. Distribution of health self-evaluation by inhabitants of Latvia in 2017.

\begin{tabular}{|l|l|l|l|l|l|}
\hline & & Frequency & Per cent & Valid per cent & Cumulative per cent \\
\hline Valid & Very good & 321 & 2,9 & 2,9 & 2,9 \\
\hline & Good & 3943 & 36,1 & 36,1 & 39,0 \\
\hline & Average & 4561 & 41,7 & 41,7 & 80,7 \\
\hline & Bad & 1733 & 15,9 & 15,9 & 96,6 \\
\hline & Very bad & 375 & 3,4 & 3,4 & 100,0 \\
\hline & Total & 10933 & 100,0 & 100,0 & \\
\hline
\end{tabular}

Source: Authors' calculations on EU-SILC data, $\mathrm{n}=10933$.

Evaluation scale 1-5: where 1= very good, 5 = very bad.

As the data given in Table 2 indicates, almost $3 \%$ of respondents evaluate their health as very good, but $3.4 \%$ as very bad. The majority of respondents evaluate their health as average, followed by a good evaluation. Almost $80 \%$ of respondents gave an evaluation of average or better.

Regional differences are also of great importance in many countries in the Republic of Latvia, as the regions are developing unevenly. According to the administrative breakdown, there are six regions in Latvia: Rīga, Pierīga, Vidzeme, Kurzeme, Zemgale and Latgale. The main statistical indicators on health self-evaluation of inhabitants by region in Latvia are given in Table 3.

Table 3. The main statistical indicators of health self-evaluation by inhabitants of regions of Latvia in 2017.

\begin{tabular}{|l|l|l|l|l|l|}
\hline LATVIA STATISTICAL REGION & Mean & N & Standard deviation & Standard error of mean & Median \\
\hline Rīga & 2,76 & 3286 & 0,815 & 0,014 & 3 \\
\hline Pierīga & 2,76 & 1644 & 0,851 & 0,021 & 3 \\
\hline Vidzeme & 2,85 & 1073 & 0,843 & 0,026 & 3 \\
\hline Kurzeme & 2,71 & 1668 & 0,864 & 0,021 & 3 \\
\hline Zemgale & 2,80 & 1595 & 0,883 & 0,022 & 3 \\
\hline Latgale & 2,99 & 1559 & 0,879 & 0,022 & 3 \\
\hline Total & 2,80 & 10825 & 0,855 & 0,008 & 3 \\
\hline
\end{tabular}

Source: Authors' calculations on EU-SILC data, n=10933.

Evaluation scale 1-5: where 1= very good, 5 = very bad. 
As the data in Table 3 indicates, the evaluation of respondents according to regions of Latvia are very similar, with more differences in evaluations by respondents from the Zemgale and Latgale regions, indicated by a bigger standard deviation. To be more specific, in conclusion, an analysis of variance (ANOVA) was used to test the statistical hypotheses on differences in mean evaluations by regions in Latvia on health selfevaluation: the results are given in Table 4.

Table 4. The main statistical indicators for testing hypothesis of health self-evaluation by inhabitants in the Latvian regions in 2017.

\begin{tabular}{|l|l|l|l|l|l|}
\hline & Sum of squares & df & Mean square & F & Sig. \\
\hline Between groups & 80,684 & 5 & 16,137 & 22,317 & 0,000 \\
\hline Within groups & 7822,863 & 10819 & 0,723 & & \\
\hline Total & 7903,547 & 10824 & & & \\
\hline
\end{tabular}

Source: Authors' calculations on EU-SILC data, $\mathrm{n}=10933$.

Evaluation scale 1-5: where 1= very good, 5 = very bad.

As the data in Table 4 indicates, the average evaluation of respondents according to regions in Latvia on health self-evaluation does not differ statistically with a level of significance of 0,000 .

To check the relationship between the urban and the rural population (note: according to the Central Statistical Bureau of the Republic of Latvia 'the breakdown of the population according to urban and rural inhabitants is made based on their permanent place of residence. The urban population refers to people who live in cities and towns, i.e., in populated areas with a usually resident population of at least 2,000. In a number of historically developed cities, the population may be less than 2,000. The status of a city or town is assigned and cancelled by the Saeima [Parliament of Republic of Latvia] by law. All the rest is considered the rural population,' CSB, 2019 A), the main statistical indicators on health self-evaluations by territory (urban and rural) in Latvia were calculated. The main results are given in Table 5.

Table 5. The main statistical indicators of health self-evaluation by inhabitants in Latvian areas in 2017.

\begin{tabular}{|l|l|l|l|l|l|}
\hline TERITORY & Mean & N & Standard deviation & Standard error of mean & Median \\
\hline Urban & 2,79 & 7209 & 0,850 & 0,010 & 3 \\
\hline Rural & 2,83 & 3616 & 0,863 & 0,014 & 3 \\
\hline Total & 2,80 & 10825 & 0,855 & 0,008 & 3 \\
\hline
\end{tabular}

Source: Authors' calculations on EU-SILC data, $\mathrm{n}=10825$.

Evaluation scale 1-5: where $1=$ very good, 5 = very bad.

The data in Table 5 indicates that health self-evaluations for rural and urban respondents are very similar; however, the arithmetical mean of health self-evaluation in rural areas is higher than in urban areas, which means that people from rural areas evaluate their health as worse than people from urban areas. However, there are also more differences in evaluations by rural respondents, indicated by a higher standard error of mean. The median health self-evaluations for urban and rural areas are the same. To be more precise and as detailed as possible, the t-test was used to test statistical hypotheses on differences in mean evaluations by respondents from urban and rural areas of Latvia on health self-evaluation. The main results of this analysis are given in Table 6. 
Table 6. The main statistical method for testing the hypothesis of health self-evaluation by inhabitants of Latvia areas in 2017.

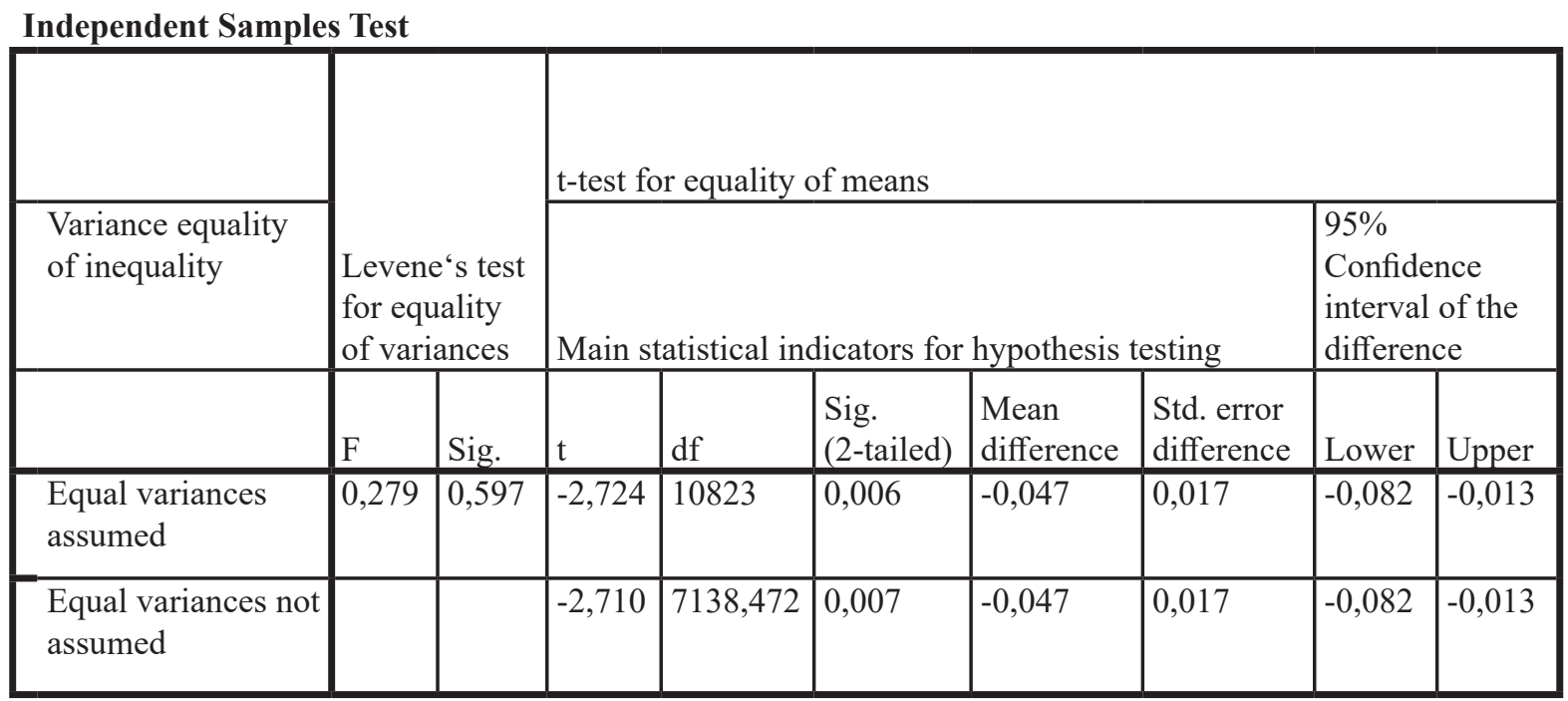

Source: Authors' calculations on EU-SILC data, $\mathrm{n}=10825$.

Evaluation scale 1-5: where 1= very good, 5 = very bad.

As the data in Table 6 indicates, the evaluations of respondents from rural and urban areas of Latvia on health self-evaluation does not differ statistically, with a level of significance of 0,006 and 0,007 .

To check the relationship strength on respondents' health self-evaluations and the highest educational level obtained in Latvia, correlation analysis was used. The results are given in Table 7.

Table 7. Correlations between health self-evaluation by inhabitants and highest educational level obtained in Latvia in 2017.

\begin{tabular}{|ll|l|l|}
\hline & & $\begin{array}{l}\text { Highest education level obtained } \\
\text { (anonymised) }\end{array}$ & Health self-evaluation \\
\hline $\begin{array}{l}\text { Highest education level } \\
\text { obtained (anonymised) }\end{array}$ & Pearson correlation & 1 &,$- 146^{* *}$ \\
\cline { 2 - 4 } & Sig. (2-tailed) & & 0,000 \\
\cline { 2 - 4 } & $\mathrm{N}$ & 10825 & 10825 \\
\hline Health self-evaluation & Pearson Correlation &,$- 146^{* *}$ & 1 \\
\cline { 2 - 4 } & Sig. (2-tailed) & 0,000 & 10825 \\
\cline { 2 - 4 } & $\mathrm{N}$ & 10825 & \\
\hline
\end{tabular}

**. Correlation is significant at the 0.01 level (2-tailed).

Source: Authors' calculations on EU-SILC data, $\mathrm{n}=10825$.

Evaluation scale 1-5: where 1 = very good, $5=$ very bad.

The data in Table 7 indicates that there is a statistically relevant correlation between the respondents' health self-evaluation and the highest educational level obtained. The Pearson correlation coefficient is statistically significant ( $p<.001$ for a two-tailed test), based on 10,825 complete observations. 


\section{Conclusions}

An analysis of theoretical research showed that health self-evaluation is a significant problem across the world, and countries often study health self-evaluation in regions by introducing new measuring instruments and indices, and adjusting them to specific national circumstances. Researchers focus on the neighbourhood impact on health self-evaluation, as well as using mortality as a measure of health self-evaluation.

The health self-evaluation rate in the European Union indicates that Latvia is below the EU28 average level (Eurostat, 2016), despite the fact that since 2011, health self-evaluation has been declining in Latvia. Estonia and Lithuania are in a slightly better situation, but also far below the EU28 average.

The health self-evaluation rate of the population by region in Latvia shows that in the Latgale and Vidzeme regions, the health self-evaluation rate is the lowest, which are less developed regions in comparison with regions closer to the capital of Latvia. The highest health self-evaluation rate is in the Rìga and Pierīga regions, which are also the most developed regions in Latvia. The analysis has revealed that there are differences in health self-evaluation in different regions in Latvia, but they are not statistically different, as well as differences in health self-evaluation by area (urban and rural areas) in Latvia, and the differences are not statistically significant.

Measuring and analysing health self-evaluation in regions will allow government authorities to facilitate the identification of areas with the greatest need, guide resource allocation and other investment, and plan health, education and other promotional programmes to reduce inequalities in regions.

Furthermore, further research into health self-evaluation in regions and its impact on different aspects of standards of living is needed. To reduce social inequalities in the population of Latvia, it is necessary to propose policy changes to ensure that Latvia's indicators rise in comparison with other EU countries.

\section{References}

Eurostat. (2017). Self-perceived health statistics. Available https://ec.europa.eu/eurostat/statistics-explained/index.php/ Self-perceived_health_statistics\#Self-perceived_health [25.11.2019.]

CSB of Republic of Latvia. (2019A). Concepts and Definitions - Urban and Rural Population. Available https://www. csb.gov.lv/en/statistics/concepts?tid=Urban+and+rural+population+\%28231\%29 [16.11.2019.]

CSB of Republic of Latvia. (2019). Statistics. Anonimised data on EU-SILC available as SPSS files for deeper analysis.

Feng, Z., Jones, K., Phillips, D. R. (2019). Social exclusion, self-rated health and depression among older people in China: Evidence from a national survey of older persons. Archives of Gerontology and Geriatrics, Vol. 82, p. 238-244.

Godhwani, S., Jivraj, S., Marshall, A., Becares, L. (2019). Comparing subjective and objective neihgbourhood deprivation and their association with health over time among older adults in England. Health and Place, Vol. 55, p. 51-58.

Gustainiené, L., Endriulaitienè, A. (2009). Job satisfaction and subjective health among sales managers. Baltic Journal of Management, Vol. 4, No. 1, p. 51-65.

Kuhlmann, E. (2003). Gender differences, gender hierarchies and professions: an embedded approach to the German dental profession. International Journal of Sociology and Social Policy, Vol. 23, No. 4/5, p. 80-96.

Lin, H., Shih, L., Lin, H. (2017). The influence of consumers' self-perceived health status and need for cognition on food-product evaluation. British Food Journal, Vol. 119, No. 2, p. 242-252.

Liu, S. R., Kia-Keating, M., Santacrose, D. E., Modir, S. (2018). Linking profiles of neighbourhood elements to health and related outcomes among children across the United States. Health and Place, Vol. 53, p. 203-209.

Mendoza-Romero, D., Urbina, A., Cristancho-Montenegro, A., Rombaldi, A. (2019). Impact of smoking and physical inactivity on self-rated health in women in Colombia. Preventive Medicine Reports, Vol. 16, p. 1-6.

Perez, E., Braen, C., Boyer, G., Mercille, G., Rehany, E., Deslauriers, V., Bilodeau, A., Potvin, L. (2019). Neighbourhood community life and health: A Systematic review of reviews. Health and Place, Article 102238.

Ronda, G., Van Assema, P., Ruland, E., Steenbakkers, M., Brug, J. (2003). The Dutch heart health community intervention "Hartslag Limburg": evaluation design and baseline data. Health Education, Vol. 103, No. 6, p. 330-341.

Šimanskienè, L., Burbulytè-Tsiskarishvili, G. (2013). Evaluation of competitiveness' factors by rural area inhabitants. Proceedings of the International Scientific Conference: Rural Development, Vol. 6, p. 628-633.

Simanskiene, L., Kutkaitis, A., Buciene, A. (2013). How to Select the Rates of Sustainable Development in Rural Territories: the Insights to Methodological Approach. Economic Science for Rural Development Conference Proceedings, Issue 31, p. 153-158. 
Simola, S. (2019). Educating business students to manage for mental health. The Journal of Mental Health Training, Education and Practice, Vol. 14, No. 5, p. 315-326.

Smyth, W., Lindsay, D., Brennan, D., Lindsay, D. (2017). Medical and allied health staff self-reported long-term conditions. International Journal of Workplace Health Management, Vol. 10, No. 6, p. 418-433.

Vîrga, D., Rusu, A. (2018). Core self-evaluations, job search behaviour and health complaints. Career Development International, Vol. 23, No. 3, p. 261-273.

Wang, W.-P., Wu, L.-H., Zhang, W., Tsay R.-M. (2019). Culturally-specific productive engagement and self-rated health among Taiwanese older adults. Social Science \& Medicine, Vol. 229, p. 79-86.

Woolf, S. H. (2019. Necessary but not sufficient: Why health care alone cannot improve population health and reduce health inequities. Annals of Family Medicine, Vol. 17., No. 3, p. 196-199.

Zhang, L., Zhou, S., Kwan, M. (2019). A comparative analysis of the impacts of objective versus subjective neighbourhood environment on physical, mental, and social health. Health and Place, Vol. 59, Article 102170.

Chaparro, M., Hughes, A., Kumari, M., Benzeval, M. (2019). Is the association between self-rated health and underlying biomarker levels modified by age, gender, and household income? Evidence from Understanding Society - the UK Household Longitudinal Study. SSM - Population Health, Vol. 8, Article 100406.

The research was supported by the NATIONAL RESEARCH PROGRAMME "LATVIAN HERITAGE AND FUTURE CHALLENGES FOR THE SUSTAINABILITY OF THE STATE” project “CHALLENGES FOR THE LATVIAN STATE AND SOCIETY AND THE SOLUTIONS IN INTERNATIONAL CONTEXT (INTERFRAME-LV)”

\title{
SVEIKATOS ISIVERTINIMAS LATVIJOS REGIONUOSE: SITUACIJOS RAIDA IR IŠŠ ÜIAI
}

\author{
Biruta Sloka, Kate Čipāne, Sabīne Anete Vasina, Emīlss Volgasts \\ Latvijos universitetas (Latvija)
}

Summary

Gyventojų sveikatos įsivertinimas Latvijoje pastaruoju metu ịgavo ypatingą reikšmę, nes šalyje sveikatos finansavimas yra vienas mažiausių Europos Sajungoje. Pastaruoju metu Latvija patiria įvairių sunkumų, tokių kaip medicinos darbuotojų atlyginimų finansavimas ir dirbti ị kitas šalis emigravusių medikų finansavimo problemos. Tyrimas atliktas siekiant išanalizuoti gyventojų sveikatos įsivertinimą Latvijos regionuose.

Tam taikyta mokslinių publikacijų ir ankstesnių tyrimų rezultatų, ES statistinių duomenų dẻ pajamų ir gyvenimo sąlygų, Europos centrinio banko atliktos apklausos dẻl namų ūkių pajamų bei išlaidų tyrimo rezultatų analizè. Rezultatai palyginti su kitų ES šalių tyrimų rezultatais. Apklausos rezultatai analizuoti remiantis aprašomosios statistikos rodikliais, atliktas kryžminis Latvijos regionų, teritorijų tarpusavio palyginimas: gyvenimo mieste ir kaime bei dispersinè analizè ANOVA - koreliacinè lyginamoji sveikatos ịsivertinimo ir išsilavinimo lygio analizè.

Tyrimo analizès rezultatai atskleidè, kad sveikatos ịsivertinimo padètis Latvijos regionuose skirtinga, tad priimantiesiems sprendimus pastaruoju metu kyla dideli iššūkiai ieškant geriausio įmanomo sprendimo.

Išanalizavus teorinius tyrimus paaiškèjo, kad sveikatos ịsivertinimas yra reikšminga problema visame pasaulyje, šalys dažnai tiria sveikatos savianalizès padėtį regionuose, naujus matavimo instrumentus ir indeksus pritaikydamos konkrečioms nacionalinėms aplinkybėms. Tyrèjai atkreipè dèmesị į kaimynystės poveikị îsivertinant sveikatą, kaip sveikatos įsivertinimo priemonè pasitelktas ir mirtingumas. 
Sveikatos įsivertinimo rodiklis Europos Sajungoje rodo, kad Latvija nesiekia ES28 vidurkio (Eurostatas, 2016), nors šalyje nuo $2011 \mathrm{~m}$. sveikatos įsivertinimas prastèja. Estijos ir Lietuvos padètis - šiek tiek geresnè, bet ir šios šalys yra gerokai žemiau ES28 vidurkio.

Gyventojų sveikatos įsivertinimo rodiklis pagal Latvijos regionus atskleidžia, kad žemiausias sveikatos ịsivertinimo rodiklis yra Latgalos ir Vidžemès regionuose, palyginti su regionais, esančiais arčiau Latvijos sostinès. Aukščiausias sveikatos ịsivertinimas fiksuotas Rygos ir Pierīgos regionuose, kurie taip pat yra labiausiai išsivystę Latvijos regionai. Atlikus analizę paaiškèjo, kad sveikatos vertinimas skirtinguose Latvijos regionuose skiriasi, bet statistiškai jie nesiskiria, be to, yra sveikatos įsivertinimo skirtumų pagal teritorijas (miesto ir kaimo vietoves), o skirtumai nėra statistiškai reikšmingi.

Išmatuotas ir analizuotas sveikatos ịsivertinimas regionuose leis valdžios institucijoms lengviau nustatyti, kur labiausiai reikia paramos, ir tikslingai paskirstyti išteklius bei kitas investicijas, planuoti sveikatos, švietimo ir kitas skatinimo programas, siekiant regionuose mažinti nelygybę.

Būtini tolesni sveikatos ịsivertinimo regionuose ir jos poveikio įvairiems gyvenimo lygio aspektams bei Latvijos gyventojų socialinès nelygybès mažinimo tyrimai, siekiant pasiūlyti rekomendacijas, kaip koreguoti politiką, kad pagerètų Latvijos rodikliai ir šalis priartètų prie kitų ES šalių.

PAGRINDINIAI ŽODŽIAI: sveikatos isivertinimas, sveikatos suvokimas, gyventoju sveikata, regionu plètra, ES pajamų ir gyvenimo salygų statistika (ES SPGS), Latvija.

JEL KLASIFIKACIJA: K2; K11

Received: 2019-12-14

Revised: 2020-01-23

Accepted: 2020-01-30 